\title{
PLURALISME PRINSIPIEL DAN REFLEKSINYA TERHADAP PANCASILA
}

\author{
Chias Yohanes Wuysang, Benyamin Fleming Intan \\ Sekolah Tinggi Teologi Reformed Injili Internasional \\ Korespondensi: kias_wuysang@yahoo.com \\ Korespondensi: benyaminintan@sttrii.ac.id
}

\begin{abstract}
ABSTRAK: Artikel ini memakai pendekatan theologis-etis dengan berfokus pada pemaparan akan hubungan agama dan negara di dalam konsep pluralisme prinsipiel dan memberikan refleksi terhadap kehidupan berbangsa dan bernegara di Indonesia yang memiliki Pancasila. Dasar theologis yang dipakai sebagai acuan adalah theologi Reformed sayap Neo-Calvinisme yang dipelopori oleh Abraham Kuyper dan diteruskan oleh pemikiran-pemikiran dari aliran Kuyperians seperti Gordon Spykman, James Skillen, Jonathan Chaplin. Penulis akan berargumen bahwa Pancasila selaras dengan pluralisme prinsipiel.
\end{abstract}

KATA KUNCI: pluralisme prinsipiel, structural pluralism, confessional pluralism, Pancasila.

ABSTRACT: This article uses theological-ethical approach to focus on the presentation of the relationship of religion and state in the concept of principled pluralism and provides a reflection on the life of the nation and state in Indonesia which has Pancasila. The theological basis used as a reference is the Reformed theology of the Neo-Calvinism wing which was pioneered by Abraham Kuyper and forwarded by ideas from Kuyperians such as Gordon Spykman, James Skillen, Jonathan Chaplin. The author will argue that Pancasila is in harmony with principled pluralism.

KEYWORDS: principled pluralism, structural pluralism, confessional pluralism, Pancasila. 


\section{Pluralisme Prinsipiel}

Istilah pluralisme prinsipiel dicetuskan pertama kali oleh James W. Skillen ${ }^{1}$ yang memberikan pengertian istilah ini di dalam website Center for Public Justice:

.... It [Principled pluralism] means recognizing that the state itself is but one institutional community among others in society. ... Principled pluralism means that government should give equal treatment to different communities of faith. Government should not have the authority to decide what constitutes true religion. Therefore, government should not try to establish one religion or to enforce secularism in public life. Most religious ways of life seek expression beyond the walls of a church. Most guide their adherents in the way they should live in society and not only in their worship and creedal confessions. Justice, therefore, requires equal treatment of religions in public as well as in private life. ${ }^{2}$

Skillen kemudian membagi pluralisme prinsipiel ini menjadi dua, yaitu structural pluralism dan confessional pluralism. ${ }^{3}$ Skillen mendefinisikan structural pluralism sebagai keberagaman dari kompetensi organisasional dan responsibilitas sosial. ${ }^{4}$ Ia berpendapat bahwa memang terdapat unsur historikal dalam proses terbentuknya keberagaman sosial, tetapi tidak dapat dipungkiri bahwa adanya identitas yang unik dari bidang keluarga, sekolah, seni, sains, politik, dan lainnya, yang kualitas karakteristiknya tidak dapat ditentukan oleh seorang individu. ${ }^{5}$ Menurut Gordon J. Spykman, structural pluralism berarti Allah mencipta dunia dengan berbagai struktur-pemerintahan sipil, pernikahan, keluarga, gereja, sekolah, pasar-yang mengatur hidup dan mengoordinasi interaksi sesama manusia. ${ }^{6}$ Dengan melihat definisi-definisi di atas, jelas bahwa konsep tentang structural pluralism bukan sesuatu yang baru tetapi berasal dari konsep sphere sovereignty Kuyper.

Structural pluralism mengikuti prinsip sphere sovereignty yaitu setiap institusi dan asosiasi adalah ordinansi dari Allah. Setiap bidang dalam masyarakat memiliki otoritasnya sendiri yang tidak boleh merebut atau

\footnotetext{
1 Jonathan Chaplin, "The Point of Kuyperian Pluralism," Comment Magazine, November 1, 2013, https://www.cardus.ca/comment/article/the-point-of-kuyperian-pluralism/.

2 "What Distinguishes CPJ," Center for Public Justice, https://www.cpjustice.org/ public/content/ what_distinguishes_cpj (diakses: 29/02/2018).

3 James W. Skillen, "The Theoretical Roots of Equal Treatment," in Equal Treatment of Religion in a Pluralistic Society, ed. Stephen V. Monsma and J. Christopher Soper (Grand Rapids: Eerdmans, 1998), 57.

4 James W. Skillen, Recharging the American Experiment: Principled Pluralism for Genuine Civic Community (Grand Rapids: Baker Pub Group, 1994), 83.

5 Ibid.

6 Gordon J. Spykman, "The Principled Pluralist Position," in God and Politics: Four Views on the Reformation of Civil Government: Theonomy, Principled Pluralism, Christian America, National Confessionalism, ed. Gary Scott Smith (Phillipsburg: P \& R, 2010), 79.
} 
mendominasi otoritas bidang yang lain. ${ }^{7}$ Ini merupakan rancangan Allah sejak semula sehingga bersifat normatif. Bidang-bidang tersebut tidaklah berdaulat secara ultimat tetapi hanya memiliki kedaulatan dalam tingkat tertentu saja di dalam wilayahnya sendiri. Menurut Spykman, setiap bidang memiliki identitas, tugas, dan hak khusus masing-masing yang diberikan oleh Allah. ${ }^{8}$ Singkatnya, kedaulatan yang dimiliki oleh setiap bidang, sifatnya adalah diberikan Allah, dependen, diturunkan, didelegasikan, dan terbatas. ${ }^{9}$ Hanya Allah yang memiliki kedaulatan ultimat. Allah mendelegasikan otoritasnya kepada manusia secara konkrit dalam berbagai bidang misalnya otoritas orang tua di rumah, otoritas khotbah di gereja, otoritas guru di sekolah, otoritas pemerintah dalam administrasi negara demi keadilan publik. ${ }^{10}$

Bagian kedua dari pluralisme prinsipiel adalah confessional pluralism. Konsep ini juga memiliki dasar dalam sphere sovereignty dari Kuyper tetapi belum dibedakan dengan jelas oleh Kuyper. ${ }^{11}$ Spykman mendefinisikan confessional pluralism sebagai hak dari kelompok-kelompok agama yang berbeda untuk terlibat dalam kehidupan publik melalui institusi mereka masing-masing - sekolah, partai politik, persatuan buruh, tempat ibadah dan lainnya-dan memperkenalkan pandangan-pandangan mereka. ${ }^{12}$ Berbeda dengan structural pluralism, confessional pluralism bukanlah normatif, karena bukan rancangan Allah sejak semula melainkan hasil dari kejatuhan manusia. Perumpamaan tentang lalang dan gandum adalah salah satu dasar Alkitab yang digunakan untuk mendukung konsep ini, ${ }^{13}$ di mana tugas untuk memisahkan mana iman yang sejati dan yang tidak sejati bukanlah tugas gereja atau negara, tetapi tugas Kristus sendiri yang akan dilakukan-Nya pada kedatangan yang kedua.

Lahirnya konsep pluralisme prinsipiel tidak lepas dari konteks tertentu. Kuyper menghadirkan konsep sphere sovereignty di antara dua pandangan, yaitu popular-sovereignty dari individualisme liberal yang mereduksi otoritas dan politik kepada kumpulan kehendak individu, dan state-sovereignty dari otoritarianisme konservatif dan sosialisme sentralis yang membuat semua otoritas sosial harus seizin negara. ${ }^{14}$ Popular-sovereignty yang Kuyper lawan

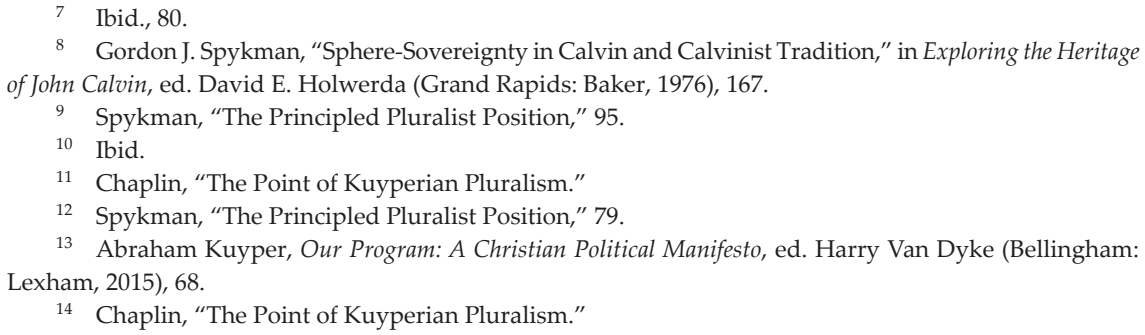

14 Chaplin, “The Point of Kuyperian Pluralism." 
adalah Revolusi Perancis yang atheistik, sedangkan state-sovereignty yang ia hadapi adalah Hegelian School of Germany yang panentheistik. ${ }^{15}$

Bagi Kuyper, di satu sisi ada yang patut disyukuri bahwa Revolusi Prancis telah menghilangkan persekongkolan antara spiritual dan politik yang terdapat di Katolik Roma, sehingga menjadi permulaan akan kebebasan politik. ${ }^{16}$ Kuyper mengatakan bahwa:

In the French Revolution; honor of liberty had been saved. Of course, those who cultivated the sinful principle of this revolution and its crimes remain guilty; God will judge them. But nonetheless, in spite of guilt and judgement Europe had received blessing! ${ }^{17}$

Di sisi lain, Kuyper juga melihat bahwa kejahatan yang sebenarnya dilakukan oleh Revolusi Prancis bukanlah ketika mereka menggulingkan dinasti Bourbon, tetapi di dalam perlawanan mereka terhadap otoritas ilahi yang dikumandangkan dalam slogan ni Dieu ni maître (no gods, no masters). ${ }^{18}$

Sedangkan keberatan Kuyper pada Hegelian School of Germany adalah dihapusnya batas antara Allah dan ciptaan. Mereka memandang negara sebagai standar moral dan hukum negara pasti adil. Negara dianggap sebagai ilah sekular. ${ }^{19}$ Bagi Kuyper seorang Calvinist hanya mengakui Allah yang berdaulat sebagai sumber segala otoritas manusia. Kuyper menjelaskan,

Therefore, in opposition both to the atheistic popular-sovereignty.... And the pantheistic state-sovereignty of German philosophers, the Calvinist maintains the Sovereignty of God, as the source of all authority among men. The Calvinist upholds the highest and best in our aspirations by placing every man and every people before the face of our Father in heaven. ${ }^{20}$

Perlawanan terhadap dua golongan ekstrem ini juga tetap diperjuangkan oleh Kuyperian yang memegang pluralisme prinsipiel, namun istilah yang dipakai adalah individualisme dan kolektivisme. Menurut Robert Nisbet, teori politik modern secara fundamental hanya tiga, yaitu individualisme, kolektivisme, dan pluralisme. Teori-teori lain hanyalah variasi dari ketiga ini. Kolektivis memegang pandangan bahwa ada satu otoritas pusat birokrasi megastruktur yang mengendalikan hidup setiap bidang masyarakat, seperti negara-kota di zaman Yunani kuno, kekaisaran

15 Abraham Kuyper, Lectures on Calvinism, 8th edition (Eerdmans, 1987), 85.

16 Ibid., 109.

17 Abraham Kuyper, "Calvinism: Source and Stronghold of Our Constitutional Liberties," in Abraham Kuyper: A Centennial Reader, ed. James D Bratt (Eerdmans, 1998), 313.

18 Peter S. Heslam, Creating a Christian Worldview: Abraham Kuyper's Lectures on Calvinism (Grand Rapids, Mich: Eerdmans, 1998), 148.

19 Ibid., 152.

20 Kuyper, Lectures on Calvinism, 90. 
di zaman Romawi kuno, Gereja Katolik Roma di abad pertengahan, dan negara-negara absolutis di zaman modern. ${ }^{21} \mathrm{Di}$ sisi lain, individualis menjadikan seorang individu berdaulat dan bebas yang menjadi bangunan dari masyarakat. Semua institusi sosial seperti pernikahan, gereja, tempat kerja, tidak memiliki status pada dirinya sendiri, dan hanyalah bersifat buatan (artificial) yang tujuannya hanya untuk manfaat bagi manusia. ${ }^{22}$ Kolektivis membatasi hak individu, sementara individualis kekurangan substansi sosial. Pluralisme prinsipiel adalah alternatif bagi keduanya.

\section{Negara}

Sebagai alternatif, pluralisme prinsipiel menawarkan pandangan yang unik mengenai negara. Allah memberikan otoritas-Nya kepada semua bidang, termasuk negara. Negara bukanlah ilah yang mengatur seluruh moralitas dan memiliki hukum dan keadilan yang mutlak harus ditaati. Negara juga bukan bidang buatan manusia untuk dimanfaatkan hanya demi kepentingan manusia seperti pandangan individualis. Pluralisme prinsipiel melihat peran pemerintah bersifat terbatas tetapi juga "ditinggikan." ${ }^{23}$ Di satu sisi, pemerintah adalah satu bidang yang setara dengan bidang-bidang sosial lainnya yang memiliki kuasa dan tanggung jawabnya sendiri dan dilarang untuk memaksakan otoritasnya kepada bidang-bidang lainnya. Namun dalam keadaan tertentu, negara memiliki pengaruh yang melebihi bidang lainnya. ${ }^{24}$ Kuyper mengatakan "Does this mean that the government has no right whatsoever of interference in these autonomous spheres of life? Not at all." ${ }^{25}$ Pertama, negara wajib mempertahankan keseimbangan antara bidang-bidang yang beragam. Jika terjadi suatu konflik, suatu bidang melewati garis batasnya, negara akan turun tangan untuk mengatur. Negara juga akan turun tangan jika dalam satu bidang tertentu terjadi pelanggaran penggunaan kekuasaan yang menindas orang lemah. Ketiga, negara memiliki hak memberlakukan pajak untuk mendukung aparat negara dan memfasilitasi tugas negara di dalam menjaga kesehatan dan kesejahteraan bangsa. ${ }^{26}$ Maka dapat dikatakan bahwa dalam bagian tertentu negara punya kedudukan lebih tinggi dari bidang lainnya, tetapi ia tetap diawasi oleh konstitusi dan perwakilan rakyat. ${ }^{27}$ Dalam Roma 13 dikatakan pemerintah diberikan kuasa oleh Allah

\footnotetext{
Spykman, "The Principled Pluralist Position," 79.

Ibid.

23 Corwin E. Smidt, "The Principled Pluralist Perspective," in Church, State and Public Justice: Five Views, ed. P. C. Kemeny (Downers Grove: IVP Academic, 2007), 136.

24 Ibid.

25 Kuyper, Lectures on Calvinism, 97.

26 Ibid.

27 Heslam, Creating a Christian Worldview, 158.
} 
tetapi sekaligus menyatakan bahwa mereka hanyalah hamba Allah, bukan pemegang kuasa mutlak.

Selanjutnya, tugas pemerintah adalah menjamin keadilan. Keadilan di sini bukan hanya mengenai menghukum para pelanggar hukum, tetapi mengenai perlakuan yang adil bagi institusi-institusi yang ada serta individu-individu yang terlibat di berbagai bidang tersebut. ${ }^{28}$ Negara dapat terlibat di institusi lain tetapi tidak boleh menguasainya. Misalnya negara harus turun tangan ketika terjadi diskriminasi dalam masyarakat, tetapi negara tidak dapat menentukan bagaimana cara orang tua mendidik anaknya. Namun jika orang tua menganiaya anaknya secara fisik apalagi sudah mengancam nyawanya, maka negara berhak campur tangan untuk menghukum orang tua itu dan memberikan perlindungan kepada anak tersebut. Ini merupakan penerapan konsep yang tidak bisa dilepaskan dari sphere sovereignty, yaitu sphere universality. Spykman mendefiniskan sphere universality sebagai "the cooperative relationship among the various social spheres; they should work together to promote wholesome community life." ${ }^{29}$ Pluralisme prinsipiel bukan hanya sadar akan keanekaragaman bidang, tetapi juga menginginkan kesatuan tujuan. Maka sphere sovereignty yang menekankan diversitas, dan universalitas bidang yang menekankan kehidupan yang bersatu, adalah komplementer yang harus dijaga. Kedua konsep ini akan melawan uniformitas dan tirani di satu sisi, dan fragmentasi dan polarisasi di sisi yang lain. ${ }^{30}$ Perhatian khusus Richard Neuhaus dan Peter Berger terhadap "mediating structures" untuk menjembatani antara kehidupan publik yang impersonal dan kehidupan pribadi yang personal sejalan dengan pemahaman kedaulatan dan universalitas bidang neo-Calvinis. ${ }^{31}$

Walaupun tugas pemerintah adalah mengejar keadilan, bukan berarti pemerintah mengejar moralitas itu sendiri. Bagian dari moralitas yang menjadi tugas pemerintah untuk diwujudkan adalah keadilan. ${ }^{32}$ Tidak semua perbuatan amoral individu wajib dihukum oleh pemerintah. Seringkali hanya hukum keenam dan kedelapan dari sepuluh hukum Taurat yang juga menjadi hukum positif dalam pemerintahan sipil. Henry Meeter berpendapat bahwa negara tidak berkewajiban untuk menerapkan kesepuluh hukum tersebut. Ia memberi contoh hukum kesepuluh "jangan mengingini" di mana seseorang ketika melanggar hukum ini tidak akan dihukum oleh negara selama keinginan itu belum diwujudkan dalam perbuatan nyata. ${ }^{33}$

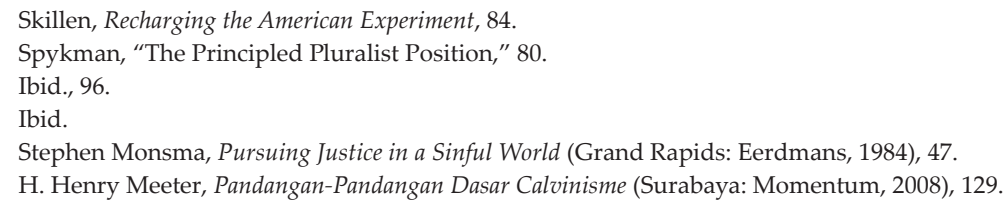


Hukum sipil tidak berhak mengadili perkara yang berkaitan dengan hati, tetapi hanya yang berkaitan dengan lahiriah. ${ }^{34}$ Negara dapat membuat aturan-aturan yang memberikan efek jera kepada pelanggar hukum, tetapi tidak dapat mengatur pikiran dan hasrat hari seseorang.

Bagian penting lainnya mengenai pandangan pluralisme prinsipiel terhadap negara adalah tugasnya sebagai agen anugerah umum, bukan anugerah khusus. Allah memberikan kuasa kepada pemerintah tetapi bukan untuk mengerjakan hal gerejawi. Negara bukan untuk memberitakan injil atau menjamin keselamatan jiwa manusia. Negara diberikan kuasa oleh Allah untuk memperhatikan kesejahteraan umum dari masyarakat. Negara tidak memiliki kuasa untuk menebus dosa manusia tetapi memiliki tugas untuk menopang tatanan ciptaan Allah. Tugas negara terbatas kepada penegakkan hukum dan keadilan publik. Maka pluralisme prinsipiel tidak mengharapkan hasil yang sempurna dan utopia karena negara tidak akan sanggup membasmi segala kejahatan dan ketidakadilan sampai Kristus datang kedua kali.

\section{Hubungan Gereja dan Negara}

Kuyper sangat menentang semangat Revolusi Perancis. Walaupun Kuyper mengakui bahwa Allah memakai Revolusi tersebut untuk menumbangkan tirani dinasti Bourbon dan memberikan penghakimannya pada para pangeran yang menginjak rakyat dengan seenaknya, tetapi sekaligus adalah anti-Kristen. Namun Kuyper juga tidak menginginkan sistem teokrasi. Bagi Kuyper pemerintahan Allah secara langsung hanya terdapat di zaman Israel:

A theocracy was only found in Israel, because in Israel, God intervened immediately. For both by Urim and Thummim and by Prophecy; both by His saving miracles and by His chastising judgments, He held in His own hand the jurisdiction and the leadership of the people. ${ }^{35}$

Maka Kuyper menolak segala bentuk Caesaropapism yang menurut dia berlawanan dengan pendirian Calvinis:

....therefore neither the Caesaropapy of the Czar of Russia; nor the subjection of the State to the Church, taught by Rome; nor the "Cuius regio eius religio" of the Lutheran jurist; nor the irreligious neutral standpoint of the French Revolution; but that only the system of a free Church, in a free State, may be honored from a Calvinistic standpoint. The sovereignty of the State and the sovereignty of the Church exist side by side, and they mutually limit each other. ${ }^{36}$

\footnotetext{
Ibid.

Kuyper, Lectures on Calvinism, 85.

Ibid., 106-7.
} 
Calvin yang mengutamakan kedaulatan Allah atas semua bidang juga menolak model kehidupan sosial Constantinian-medieval yang telah mendominasi Kekristenan Barat selama 1200 tahun. ${ }^{37}$ Hanya firman Allah yang berotoritas masing-masing atas gereja dan negara secara unik, bukan berbagi kekuasaan di antara keduanya. Dalam Institutes IV.XX.1 Calvin katakan "Christ's spiritual Kingdom and the civil jurisdiction are things completely distinct." Dalam tafsiran Calvin pada 1 Petrus 2:12-17, "Tunduklah, karena Allah, kepada semua lembaga manusia, baik kepada raja sebagai pemegang kekuasaan yang tertinggi," (ayat 13), Calvin berpendapat:

The verb KTIZEIN in Greek, from which KTISIS comes, means to form or construct a building. It corresponds to the word "ordinance," by which Peter reminds us that God the Maker of the world has not left the human race in state of confusion, so that we live after the manner of beast, but has given tehm, as it were, abuilding regularly formed, and divided into several compartments. It is called a human ordinance, not because it has been invented by men, but because it is a mode of living well-arranged and clearly ordered, approriate to man. ${ }^{38}$

Di sini Calvin telah memiliki benih konsep structural pluralism walaupun hanya bidang gereja dan negara yang jelas ia bedakan, tetapi pemikiran Calvin bahwa Allah berdaulat atas setiap bidang akan konsisten dengan ide pluralisme struktual yang juga jelas membedakan batasan kedaulatan antara bidang-bidang lain dalam masyarakat. ${ }^{39}$

Lebih lanjut, perlu diingat bahwa Calvin hidup dalam konteks di mana orang pada umumnya masih berpikir bahwa Christendom akan terus berlanjut, Kristen akan terus mayoritas, dan belum mengantisipasi akan munculnya berbagai macam iman, baik iman agama maupun non-agama di ruang publik. Maka Calvin belum mengantisipasi akan adanya confessional pluralism.

Meskipun Kuyper mengaku dirinya adalah seorang murid dan penyalin (copyist) dari Calvin, tidak berarti ia harus menyetujui semua pemikiran Calvin. Henry Van Til berpendapat bahwa Kuyper adalah seorang penyalin Calvin namun bukan dengan mental penurut yang tidak kritis. Van Til menulis,

Kuyper's views have been called Neo-Calvinism, in spite of his own plea of faithfulness to the master, is due to the fact that Kuyper was not a slavish copyist but worked on in the spirit of Calvin. Hence we must not look for repristination pure and simple, nor an uncritical admiration of Calvin by his

\footnotetext{
Spykman, "The Principled Pluralist Position," 84.

8 Ibid.

Ibid.
} 
reat disciple. ${ }^{40}$

Salah satu keberatan Kuyper terhadap Calvin adalah tentang kewajiban negara dalam melawan segala bentuk penyembahan berhala dan agama yang salah. ${ }^{41}$ Ia merujuk kepada Pengakuan Iman Belgia pasal 36,

And their office is, not only to have regard unto, and watch for the welfare of the civil state; but also that they protect the sacred ministry; and thus may remove and prevent all idolatry and false worship; that the kingdom of antichrist may be thus destroyed and the kingdom of Christ promoted..$^{42}$

Yang Kuyper sayangkan adalah Pengakuan Iman ini mendapat restu yang bulat dari Calvin dan para pendukungnya yang menurut Kuyper justru bertentangan dengan Calvinisme. ${ }^{43}$ Guido De Bres, penulis Pengakuan Iman Belgia, adalah murid Calvin yang pernah belajar di bawah Calvin di Frankfurt (1556), Lausanne (1559), dan Geneva (1559). ${ }^{44}$ De Bres mengirim draft Pengakuan Iman Belgia ke Geneva sebelum diterbitkan untuk mendapatkan persetujuan. ${ }^{45}$

Poin Calvin ini sebelumnya sudah ia tulis dalam Institutes IV:XX:2 "civil government is designed, as long as we live in this world, to cherish and support the external worship of God, to preserve the pure doctrine of religion, to defend the Constitution of the church." Calvin berpendapat bahwa pemerintah memiliki kewajiban untuk menjamin "that idolatry, sacrileges against the name of God, blasphemies against his truth, and other offenses against religion may not openly appear and be disseminated among the people...."46

Kuyper berargumen bahwa negara yang diwajibkan untuk melawan segala bentuk berhala dan agama yang salah tidak terdapat dalam Calvinisme tetapi dari Konstantinus Agung yang merupakan reaksi dari penganiayaan yang dilakukan oleh kaisar kafir sebelumnya terhadap para pengikut Yesus. Sistem ini dianut oleh Katolik Roma selama ratusan tahun. Reformator banyak mereformasi ajaran Katolik Roma, tetapi dalam hal menggunakan kuasa pemerintah untuk menghukum bidat, belum mengalami reformasi. Francois Wendel mencatat bahwa,

Calvin was convinced, and all the reformers shared this conviction, that it was the duty of a Christian magistrate to put to death blasphemers who kill the

40 Henry R. Van Til, The Calvinistic Concept of Culture (Grand Rapids: Baker Academic, 2001), 117.

41 Kuyper, Lectures on Calvinism, 99.

42 "The Belgic Confession (1561)," Ligonier Ministries, https://www.ligonier.org/learn/ articles/belgic-confession-1561/ (diakses: 01/08/2018).

43 Kuyper, Lectures on Calvinism, 99.

44 S.A. Strauss, "John Calvin and the Belgic Confession," Die Skriflig 27, no. 4 (1993): 504.

45 Cornelis P. Venema, “The Belgic Confession," Tabletalk Magazine, 2008.

46 John Calvin, Institutes of the Christian Religion, ed. John T. McNeill, trans. Ford Lewis Battles (Philadelphia; London: Westminster John Knox Press, 1960). 
soul, just as they punished murderers who kill the body. ${ }^{47}$

Philipp Melanchthon menanggapi penghukuman Servetus dengan menulis surat kepada Calvin pada tanggal 14 Oktober 1554 untuk menyatakan persetujuannya:

I have read the writing in which you have refuted the detestable blasphemies of Servetus, and I return thanks to the Son of God who was the arbiter of your combat. To you also, the Church owes, and will in the future owe, gratitude. I am in entire agreement with your judgment. I affirm also that your Magistracy has acted justly in putting this blasphemer to death after a regular trial. ${ }^{48}$

Calvin sendiri tidak memasukan kewajiban negara untuk menghukum penista agama ke dalam Pengakuan Iman Jenewa tahun 1536 pasal 21, tetapi pengakuan iman lainnya yang memasukan. Selain Pengakuan Iman Belgia pasal 36, yang juga memasukannya adalah Pengakuan Iman Westminster pasal 23,

It is the duty to take order, that unity and peace be preserved in the Church, that the truth of God be kept pure and entire, that all blasphemies and heresies be suppressed, all coruptions and abuses in worship and discipline prevented or reformed, and all the ordinances of God duly settled, administered, and observed. ${ }^{49}$

Pengakuan Iman Skotlandia pasal 24,

.... not only they are appointed for civil policy, but also for maintenance of the true religion, and for suppressing of idolatry and superstition whatsoever: as in David, Jehoshaphat, Hezekiah, Josiah, and others, highly commended for their zeal in that case, may be espied. ${ }^{50}$

\section{Pengakuan Iman Helvetika Kedua pasal 30,}

.... he promotes the preaching of the truth and sincere faith, roots out lies and all superstition, together with all impiety and idolatry, and defends the Church of God.... Let him suppress stubborn heretics (who are truly heretics), who do not cease to blaspheme the majesty of God and to trouble, and even to destroy the Church of God. ${ }^{51}$

Bagi Kuyper, negara justru wajib untuk toleran terhadap berbagai jenis denominasi gereja karena negara tidak berkompetensi untuk menghakimi

\footnotetext{
47 François Wendel, Calvin: Origins and Development of His Religious Thought, trans. Philip Mairet, 1st Labyrinth Press Ed edition (Baker Academic, 1995), 97.

48 Ibid.

49 "Westminster Confession of Faith," https://reformed.org/documents/wcf_with_proofs/ (diakses: 01/08/2018).

50 “Scottish Confession of Faith (1560)," http://www.swrb.com/newslett/actualNLs/ ScotConf. htm\#CH24 (diakses: 01/08/2018).

51 “The Second Helvetic Confession," https://www.ccel.org/creeds/helvetic.htm (diakses: 01/08/2018).
} 
hal spiritual, dan negara akan menyalahi kedaulatan gereja. ${ }^{52} \mathrm{Di}$ tahun 1890-an Kuyper mengajukan penghapusan kata-kata "thus may remove and prevent all idolatry and false worship" dari Pengakuan Iman Belgia pasal $36 .{ }^{53}$ Tahun 1905 referensi pada pasal 36 yang berkaitan dengan kewajiban negara melawan agama yang salah telah dihapus oleh the General Synod of the Reformed Churches di Belanda. Demikian Pengakuan Iman Westminster direvisi oleh gereja Presbyterian di Amerika tahun 1900, khususnya pasal 23 mengalami penulisan ulang secara total. ${ }^{54}$

Alasan gereja Reformed dan Presbyterian merevisi pasal-pasal dalam beberapa pengakuan iman mengenai tugas pemerintah adalah berdasarkan Alkitab. Ayat yang dipakai untuk mendukung Pengakuan Iman Belgia pasal 36 misalnya 1 Raja-Raja 15:12 mengenai raja Asa menyingkirkan pelacuran bakti dan segala berhala yang dibuat oleh nenek moyangnya, lalu 2 Raja-Raja 23 mengenai reformasi Yosia di mana dicatat para imam bukit pengorbanan disembelih olehnya. Penggunaan ayat-ayat ini untuk membenarkan campur tangan negara untuk membasmi berhala adalah tidak tepat karena konteks Israel sebagai bangsa pilihan Allah sudah tidak sama dengan hari ini dan tidak dapat diberlakukan kepada gereja atau negara mana pun. Hari in tidak ada lagi bangsa yang disebut sebagai umat pilihan Allah. Tidak ada pemimpin yang memiliki posisi seperti raja Daud yang tugasnya mengatur liturgi dan mempersiapkan pembangunan bait Allah. Gereja pun hari ini sebagai umat Allah, dalam melaksanakan disiplin gereja kepada jemaatnya sendiri, tidak seperti zaman Israel yang menyembelih atau membakar nabi palsu.

Lebih lanjut mengenai Israel, meskipun saat itu memiliki status sebagai umat Allah, mereka tetap menghargai kebebasan beragama. Yang perlu diingat, perintah Allah "Jangan ada padamu Allah lain di hadapan-Ku" adalah perintah ini ditujukan kepada Israel, bukan kepada bangsa lain. Menurut Paul Marshall, bangsa di luar Israel dibebaskan untuk menganut kepercayaannya masing-masing. Marshall mencatat,

Israel was called to be a particular nation whose political and social order rested on belief and trust in Yahweh, an order that would be radically disrupted if other religious ways of life intruded. However, the surrounding nations were left free to follow their own faiths. ${ }^{55}$

\footnotetext{
52 Kuyper, Lectures on Calvinism, 105.

53 L. Kalsbeek, Contours of a Christian Philosophy, ed. Bernard Zylstra and Josina Zylstra (Toronto: Wedge Publishing Foundation, 1975), 229.

54 "American Revisions to the Westminster Confession of Faith," https://www.opc.org/ documents/ WCF_orig.html (diakses: 02/08/2018).

55 Paul Marshall, God and the Constitution: Christianity and American Politics (Lanham: Rowman \& Littlefield, 2002), 114.
} 
Bahkan ketika ada bangsa asing yang tinggal di Israel, mereka pun tidak dipaksa pindah agama. Keluaran 20:21 "Janganlah kautindas atau kautekan seorang orang asing, sebab kamupun dahulu adalah orang asing di tanah Mesir.” Keluaran 23:9 “Orang asing janganlah kamu tekan, karena kamu sendiri telah mengenal keadaan jiwa orang asing, sebab kamupun dahulu adalah orang asing di tanah Mesir." Israel dalam perbudakan di Mesir tetap dibebaskan untuk beriman dan menyembah Allah. Mereka mengerti bagaimana menjadi penduduk asing, maka mereka memperlakukan orang asing di tanah mereka dengan baik.

Namun Marshall juga mencatat adanya pengecualian. ${ }^{56}$ Seperti yang tercantum di dalam Imamat 20:2: “Engkau harus berkata kepada orang Israel: Setiap orang, baik dari antara orang Israel maupun dari antara orang asing yang tinggal di tengah-tengah orang Israel, yang menyerahkan seorang dari anak-anaknya kepada Molokh, pastilah ia dihukum mati, yakni rakyat negeri harus melontari dia dengan batu."

Di sini hukuman mati diberlakukan kepada orang Israel maupun orang asing. Alasannya adalah karena penyembahan kepada Molokh mengikutsertakan penyerahan anak-anak. Di sini mengindikasikan bahwa ada praktek agama tertentu yang tidak boleh ditoleransi dalam konteks Israel sebagai bangsa pilihan Allah.

Jika di Perjanjian Lama terdapat toleransi kepada agama lain, Perjanjian Baru lebih jelas lagi. Gereja yang adalah umat Allah sudah tidak lagi diikat oleh jenis suku dan wilayah teritorial sehingga lebih lebar membuka pintu kepada orang manapun untuk masuk tetapi bukan dengan paksaan. Rasulrasul yang adalah utusan langsung dari Kristus tidak berkhotbah dengan paksaan, tetapi dengan undangan untuk menerima Yesus. Lebih lanjut, Skillen berpendapat bahwa Yesus bukan saja memerintahkan untuk tidak memaksa tetapi justru harus mengasihi musuh dan memperjuangkan kesejahteraan mereka yang mungkin berbuat jahat kepada kita. ${ }^{57}$

Jika kembali kepada pluralisme prinsipiel, apa yang Kuyper lawan adalah pelanggaran terhadap confessional pluralism yang juga mengakibatkan pelanggaran terhadap structural pluralism. Negara yang membasmi suatu denominasi tertentu atau bahkan bidat berarti tidak mengakui atau tidak toleran terhadap pluralitas iman warganya dan sudah melanggar confessional pluralism. Pada saat yang sama, negara sedang merebut kedaulatan agama dalam menentukan ajarannya sendiri, yang berarti menyalahi structural pluralism. Menurut Jonathan Chaplin, confessional pluralism sangat bergantung

56 Ibid., 115.

57 James W. Skillen, ed., Confessing Christ and Doing Politics (Center for Public Justice, 1802), 55. 


\section{kepada structural pluralism. ${ }^{58}$}

Masalah lainnya mengenai pelanggaran terhadap confessional pluralism adalah mereduksinya hanya kepada kehidupan privat dan ibadah sempit dalam gereja lokal saja. Confessional pluralism tidak cukup dengan sekadar memproteksi gereja atau tempat ibadah agama lain. Confessional pluralism harus dimengerti tentang pengertian agama yang menyeluruh. Marshall menjelaskan bahwa,

Religion - whether true or false - is not only a matter of participating in religious ceremonies or embracing a set of purely theological beliefs, it is not simply the formal act of worshipping God or an idol. It is about the core beliefs that shape human life. Hence, freedom of religion is far more than freedom of worship. It necessarily includes freedom of thought, freedom of assembly, and freedom of speech. Conversely, denying religious freedom can also mean denying these things as well. Religion and worship, whether true or false, are intimately tied to living out what we believe in our lives. ${ }^{59}$

Menyempitkan agama hanya ke dalam masalah privat adalah pandangan dari sekularisme. Mereka berpikir bahwa dunia publik adalah milik sekular dan bebas dari pemikiran religius. Bagi pluralisme prinsipiel pandangan ini jelas tidaklah adil. Padahal pluralisme prinsipiil bukan menolak keberadaan orang yang memiliki cara pandang atau iman nonagama untuk hidup bersama di dunia publik karena itu adalah bagian dari confessional pluralism yang menjamin kebebasan berpikir, berkumpul, dan berbicara. Namun yang dilakukan oleh penganut sekularisme adalah menolak keberadaan penganut cara pandang atau iman agama untuk dibicarakan di ranah publik. Maka dapat dikatakan bahwa kaum sekularis sedang melawan kebebasan beragama. Padahal agama Kristen misalnya, diperintahkan oleh kitab sucinya untuk mempraktekkan imannya di seluruh aspek hidup, bukan hanya di gereja. Orang Kristen dipanggil untuk masuk dalam bidang hukum, politik, ekonomi, ilmu pengetahuan dan segala bidang kehidupan yang nyata setiap hari. Maka pemerintah seharusnya menjamin kebebasan beragama yang diekspresikan dalam setiap profesi seseorang. Jika menyempitkan kebebasan beragama hanya di wilayah privat berarti sama saja dengan tidak mengakui kebebasan beragama.

Pandangan sekularisme di atas juga mengasumsikan adanya dasar netral yang sifatnya non-religius. Pluralisme prinsipiil menentang pandangan tersebut karena seluruh hidup manusia bersifat religius baik agama dan non-agama sekalipun sama-sama memiliki presuposisi dasar

58 Jonathan Chaplin, "Christianity, the State and Religious Pluralism" (Intensive Course, Sekolah Tinggi Theologi Reformed Injili Internasional, March 28, 2018).

59 Marshall, God and the Constitution, 114. 
mengenai apapun yang mereka praktekkan di wilayah privat maupun publik. Misalnya seseorang memperjuangkan tentang keadilan yang ia klaim bukan dari konsep agama mana pun, jika ditelusuri mungkin saja ia memakai pemikiran filsafat Yunani atau yang lainnya. Artinya setiap orang tidak bisa lepas dari presuposisi tertentu sehingga tidak mungkin melarang orang lain untuk memiliki presuposisi tertentu juga.

Salah satu tuduhan kepada pluralisme prinsipiil adalah konsep ini memimpin kepada perang kebudayaan. Skillen melawan pandangan yang berpendapat bahwa konflik kebudayaan secara sederhana disebabkan oleh permusuhan politik dan sosial yang memiliki dasar sistem moral yang berbeda yang pada ujungnya adalah satu budaya mendominasi kebudayaan yang lainnya. ${ }^{60}$ Tetapi dari pengamatan Skillen, konflik antara Protestan dan Katolik di Amerika misalnya, bukan disebabkan oleh alasan moral atau religius, tetapi karena perebutan mengenai status sekolah. Di sini perang kebudayaan terjadi bukan karena perbedaan theologi atau cara pandang yang diajarkan oleh agama masing-masing, tetapi karena kepentingan lain.

\section{Pluralisme Prinsipiil dan Relativisme}

Pluralisme prinsipiil adalah suatu argumentasi moral untuk negara yang adil yang bersifat utuh dan bukan sebagai ekspresi dari relativisme moral. ${ }^{61}$ Pluralisme prinsipiil tentu mengakui adanya kebenaran sehingga memandang bahwa tidak semua praktek hidup sosial manusia adalah benar. Tentu ada pandangan ekonomi yang salah, politik yang salah, seni yang salah, keluarga yang salah, dan seterusnya. Pluralisme prinsipiil terbatas dalam tujuannya untuk adanya kejelasan normatif di bidang hukum dan politik. ${ }^{62}$ Pemerintah harus berdasarkan konstitusi untuk menyatukan masyarakat di bawah hukum dan menjamin setiap warga negara diperlakukan sama dan dilindungi dengan baik. Pluralisme prinsipiil mengafirmasi bahwa sistem negara hanya boleh satu. Ketika mengatakan bahwa negara harus dibatasi dan harus mengakui kedaulatan dalam bidang-bidang lainnya, tidak berarti kedaulatan negara yang telah memiliki satu jenis sistem pemerintahan boleh disaingi oleh sistem lain. Sistem pancasila misalnya, akan terancam jika ada golongan yang menjalankan sistem negara agama.

Demikian halnya tentang kebebasan beragama. Ketika pluralisme prinsipiil tidak menyetujui gereja melakukan hukuman mati kepada Servetus, tidak berarti sedang membela ajaran bidat yang dianut oleh Servetus melainkan membela hak dia untuk hidup dan berpendapat. Tetapi jika

\footnotetext{
Skillen, Recharging the American Experiment, 87.

Ibid., 99.

62 Ibid.
} 
apa yang ia lakukan adalah perbuatan kriminal secara hukum maka ia boleh diproses sesuai hukum yang berlaku. Berarti kebebasan beragama pun bukan sebebas-bebasnya.

\section{Pancasila}

Di Indonesia, hubungan antara agama negara terdapat coraknya di dalam Pancasila. Soekarno mengumandangkan bahwa filsafat (Philosophische Grondslag atau Weltanschauung) negara Indonesia adalah Pancasila dalam pidatonya di sidang Badan Penyelidik Usaha-usaha Persiapan Kemerdekaan Indonesia (BPUPKI) pada 1 Juni $1945 .{ }^{63}$ Meskipun terjadi jalan buntu karena perdebatan sengit antara faksi nasionalis dan faksi Islam yang sebelumnya memasukkan kata-kata "dengan kewajiban menjalankan syariat Islam bagi pemeluk-pemeluknya", pada 18 Agustus, yaitu satu hari setelah proklamasi kemerdekaan, Hatta mengusulkan untuk menghapus "tujuh kata" tersebut. ${ }^{64}$

Maka rumusan Pancasila menjadi:

1. Ketuhanan Yang Maha Esa,

2. Kemanusiaan yang adil dan beradab,

3. Persatuan Indonesia

4. Dan kerakyatan yang dipimpin oleh hikmat kebijaksanaan dalam permusyawaratan perwakilan

5. Serta dengan mewujudkan suatu keadilan sosial bagi seluruh rakyat Indonesia.

Soekarno menegaskan bahwa bangsa Indonesia bukan saja bertuhan tetapi bertuhan menurut agamanya masing-masing dengan bebas dan tanpa adanya egoisme agama. ${ }^{65}$ Pancasila tidak mengusung negara agama yang memiliki agama tunggal, melainkan memberikan kebebasan warganya untuk beribadah sesuai dengan agama dan kepercayaan masing-masing seperti tercantum dalam pasal 29 UUD 1945 yang merupakan konstitusi negara. Soekarno bahkan pernah mengklaim bahwa orang atheis pun menoleransi sila pertama dan keberadaan mereka tidak dilarang di Indonesia. ${ }^{66}$ Pancasila menolak sacred public square, di mana yang menjadi tolok ukurnya bukanlah keadilan, tetapi satu agama, yang bersifat superior, eksklusif, diskriminatif, memiliki hak istimewa bagi mayoritas, melawan semangat

63 Soekarno, "Pidato Lahirnya Pancasila 1 Juni 1945" (Jakarta, 2007).

64 Denny Indrayana, Amandemen UUD 1945: Antara Mitos Dan Pembongkaran (Jakarta: Mizan, 2010), $55-56$.

65 Soekarno, "Pidato Lahirnya Pancasila 1 Juni 1945."

66 Soekarno, "To Build The World A New" (United Nations, September 30, 1960). Meskipun atheis tidak bergabung atau menolak agama secara institusi atau organisasi, atheis sendiri tidak bisa lepas dari sifat agama secara internal dalam dirinya. 
bhinneka tunggal ika, dan anti demokrasi. ${ }^{67}$

Meskipun bangsa Indonesia adalah bangsa yang beragama, tetapi kehidupan keagamaannya tidak hanya dilakukan di ruang privat. Mark Woodward berpendapat bahwa masyarakat Indonesia belum pernah mengalami derajat sekularisasi seperti yang dimiliki masyarakat barat. ${ }^{68}$ Privatisasi agama yang menjadi salah satu karakteristik dari negara-negara barat tidak menjadi karakteristik dari Indonesia. Agama tetap merupakan salah satu faktor terpenting dalam kehidupan publik secara umum. ${ }^{69}$ Lebih lanjut, Woodward menjelaskan:

Indonesian religion, in all its forms, remains very public and plays a central role in social and political discourse. Religious diversity is simply a fact. The fact that Indonesia is the world's most populous Muslim nation does not change the fact that it is and will remain characterized by religious diversity. ${ }^{70}$

Terhindarnya Indonesia dari corak privatisasi agama seperti di negara barat tidaklah mengherankan, mengingat bahwa baik Soekarno maupun Hatta sejak awal telah mengritik akan demokrasi tipe negara barat. Masih dalam pidato 1 Juni 1945, Soekarno telah menegaskan bahwa demokrasi yang dimiliki barat hanyalah politieke democratie (demokrasi politik), tanpa sociale democratie (demokrasi sosial), social rechtvaardigheid (keadilan sosial), dan ekonomische democratie (demokrasi ekonomi). Hatta juga mengritik individualisme barat yang telah mengakibatkan kehidupan sosialnya hancur karena kapitalisme yang telah menjajah ekonomi dan politik. ${ }^{11}$

Kehidupan beragama yang muncul di ruang publik dapat mencegah terjadinya radikalisme agama. Agama akan bereaksi keras jika terjadi privatisasi agama seperti dalam konsep naked public square. Reaksi agama yang diikuti dengan unsur balas dendam tersebut akan mengganggu ketertiban umum. ${ }^{72}$ Marshall berpendapat bahwa ada dua faktor yang menghambat kebebasan agama, yaitu negara yang menjadikan satu agama sebagai agama negara dan negara yang terlalu sekuler yang menekan ekspresi agama di ruang publik..$^{73}$ Kendati tidak dapat dipungkiri bahwa terdapat kelompok

67 Benyamin F. Intan, “Pancasila, Agama, dan Ranah Publik," Reformed Center for Religion \& Society, June 1, 2011, para. 7, https://reformed-crs.org/pancasila-agama-dan-ranah-publik/.

68 Mark Woodward, "State-Religion Relations in Indonesia," in Dealing with Diversity: Religion, Globalization, Violence, Gender and Disaster in Indonesia, ed. Bernard Adeney-Risakotta, 17 (Geneva: Globethics. net, 2014), 74 .

69 Ibid.

70 lbid., 77.

71 Jakob Tobing, “Nasionalisme dan Sejarah Konstitusi Indonesia," in Institut Leimena (Ceramah pada Peserta PPRA LVIII Lemhannas 2018, Jakarta, 2018).

72 Benyamin F. Intan, "Pancasila, Agama, dan Ranah Publik," Reformed Center for Religion \& Society, June 1, 2011, https://reformed-crs.org/pancasila-agama-dan-ranah-publik/.

73 Paul Marshall, "Hubungan Agama-Agama dan Hukum Nasional Dalam Masyarakat Majemuk" (Round Table Discussion, Kampus Universitas Kristen Indonesia, Cawang, Jakarta, Oktober 2014), https:// 
radikalisme agama di Indonesia, namun menurut Ahmad Syafii Maarif, Indonesia terlalu besar untuk dihancurkan oleh kelompok tersebut sehingga segala usaha yang dilakukan oleh fenomena yang sifatnya hanya sementara ini akan sia-sia saja. ${ }^{74}$ Menurut Maarif, maraknya bom bunuh diri yang dilakukan oleh para ekstrimis, yang ia sebut sebagai "rongsokan peradaban $\mathrm{Arab}^{\prime},{ }^{75}$ akan segera berakhir ketika Indonesia dapat mengatasi persoalan ekonomi. ${ }^{76}$

Eka Darmaputera menunjukkan keunikan Pancasila mengenai hubungan agama dan negara yang berbeda dengan negara-negara lainnya:

This is one of the unique characteristics of our Pancasila state. In a secular state, religion is a private matter, it has no official role in the societal, national, and state life. In a religious state, one religion has a legitimate role and place, but not religions. Only in a Pancasila state, all religons have a legitimate role and common responsibility, and all these have to be carried out in togetherness. ${ }^{77}$

"Togetherness" yang dimaksud oleh Darmaputera bukanlah hidup bersama tanpa "kebersamaan" dan dialog yang ikhlas (peaceful co-existence), tetapi hidup dalam kerja sama satu dengan lainnya (creative pro-existence). ${ }^{78}$ Meskipun hidup dalam perbedaan identitas dan keyakinan tetapi memiliki tujuan bersama untuk kepentingan semua.

\section{Pengaruh Pluralisme Prinsipiil terhadap Pancasila}

Lahirnya Pancasila yang dipaksakan dengan cara kompromi antara faksi Islam dan faksi nasionalis tersebut memang harus diakui tidak menyelesaikan masalah sampai tuntas. Perseteruan antara kedua faksi tersebut kembali terpampang jelas setelah Indonesia merdeka 54 tahun, yaitu pada pemilihan presiden tahun 1999 antara Gus Dur dan Megawati, yang menurut Darmaputera diselesaikan dengan cara khas neither-nor, kompromi, tidak ada yang menang dan yang kalah sepenuhnya. Lanjutnya, cara tersebut adalah nama lain dari penundaan masalah. ${ }^{79}$ Namun kompromi yang

leimena.org/blog/2014/11/04/jadikan-pancasila-sebagai-rujukan/, https://leimena.org/blog/2014/11/04/ jadikan-pancasila-sebagai-rujukan/.

74 Ahmad Syafii Maarif, "Pluralism as a Hard Fact of History," in Dealing with Diversity: Religion, Globalization, Violence, Gender and Disaster in Indonesia, ed. Bernard Adeney-Risakotta, 17 (Geneva: Globethics. net, 2014), 86.

75 Widiarsi Agustina, “Buya Syafii Maarif Sebut ISIS Itu Rongsokan Peradaban Arab," Tempo, July 17, 2017, https://nasional.tempo.co/read/892178/buya-syafii-maarif-sebut-isis-itu-rongsokan-peradaban-arab.

76 Maarif, "Pluralism as a Hard Fact of History," 86.

77 Eka Darmaputera, “Inter-Relationship Among Religious Groups in Indonesia: Peaceful Co-Existence or Creative Pro-Existence," in Masihkah Benih Tersimpan..?: Kumpulan Karangan Dalam Rangka 50 Tahun GKI Jawa Barat, ed. F. Suleeman and Ioanes Rakhmat (Jakarta: BPK Gunung Mulia, 1990), 38.

78 Ibid., 35.

79 Eka Darmaputera, Pergulatan Kehadiran Kristen Di Indonesia: Teks-Teks Terpilih Eka Darmaputera, Cet. 1 edition (Jakarta: BPK Gunung Mulia, 2001), 396. 
menghasilkan indikasi hubungan antara negara dan agama sebagai "neither secular, nor theocratic" tersebut secara mengherankan menyerupai konsep agama dan negara yang diusulkan oleh pluralisme prinsipiil.

Fakta bahwa Pancasila sesuai dengan pluralisme prinsipiil membuka pintu untuk menghubungkan apakah Pancasila lahir di bawah pengaruh pluralisme prinsipiil atau tidak. Klaim ini didukung oleh 3 alasan: pertama, fakta bahwa 350 tahun kolonialisme Belanda di Indonesia telah membawa pengaruhnya lewat gereja-gereja Reformed di Indonesia. Kedua, mengutip J. M. van der Kroef yang menunjukkan bahwa dalam 4 butir Pancasila terdapat istilah-istilah seperti kemanusiaan, nasionalisme, demokrasi, dan keadilan sosial, bukan hanya istilah dari barat, namun terdapat pengaruh barat dalam formulasinya. Ketiga, mengutip Eric Louw yang mengatakan bahwa Kuyperian pluralism "gave shape to Pancasila so that religious pluralism is enforced and thereby the idea of majoritarianism blocked." 80

Sebagai tambahan, Soekarno sendiri diketahui memiliki penghargaan terhadap Kuyper. Dalam pidato pembelaannya pada tahun 1930 di Landraad Bandung yang dikenal dengan judul Indonesia Menggugat, Soekarno mengutip Kuyper dari buku Antirevolutionaire staatkunde yang memaparkan secara objektif mengenai keuntungan dan kerugian yang bisa diakibatkan oleh penjajahan, dan menyebut Kuyper sebagai "pemimpin besar." ${ }^{11}$

Maka berdasarkan pemaparan di atas, jelaslah bahwa pluralisme prinsipiil dan Pancasila bukanlah dua hal yang tanpa point of contact. Fakta bahwa pluralisme prinsipiil memiliki pengaruh pada Pancasila bukanlah sesuatu yang harus dilerai, tetapi dieratkan.

Usaha menginterpretasi Pancasila berdasarkan pluralisme prinsipiil juga telah mengantisipasi fakta bahwa Indonesia memiliki penduduk Muslim terbesar di dunia. Islam tentu tidak mudah menerima suatu teori yang berasal dari Kristen. Menurut John L. Esposito dan John O. Voll:

The relationship between Islam and democracy is strongly debated among the people who identify with the Islamic resurgence in the late twentieth century and the beginning of the twenty-first. Some of these Islamists believe that "democracy" is a foreign concept that has been imposed by Westernizers and secular reformers upon Muslim societies. They often argue that the concept of popular sovereignty denies the fundamental Islamic affirmation of the sovereignty of God and is, therefore, a form of idolatry. People holding these views are less likely to be the ones participating in elections. Many limit themselves to participating in intellectual debates in the media, and others hold themselves aloof from the political dynamics of their societies, hoping that their own isolated community will in some way be an inspiration to the

80 Benyamin F. Intan, "Religious Freedom and The Pancasila-Based State of Indonesia: A Neo-Calvinist Idea of Principled Pluralism" (Gaffin Lecture, Philadelphia: Westminster Theological Seminary, 2018).

81 Soekarno, "Indonesia Menggugat” (Pidato Pembelaan di Landraad, Bandung, 1930). 
broader Muslim community. ${ }^{82}$

Dari kutipan di atas, Esposito dan Voll memaparkan bahwa Islam sulit menerima demokrasi karena terdapat konsep popular sovereignty yang bertentangan dengan sovereignty of God. Bagi Islam, menerima yang satu berarti harus menolak yang lainnya. Partisipasi mereka di ruang publik pun sedikit dan lebih memilih isolasi.

Namun, masalah either/or pada Islam dalam menghadapi demokrasi modern di abad ke-20 dan ke-21 ini telah mendapat solusinya pada abad ke-19 oleh Neo-Calvinisme. Seperti yang pernah dikemukan oleh John L. Hiemstra bahwa:

.... Christianity that is particularly relevant on this question, namely Dutch neo-Calvinism. This tradition shares with many Christian traditions a deep commitment to the "sovereignty of God," as it does with Islam, but remarkably neo-Calvinism emerged as an early promoter of democracy. It produced a rich and vigorous tradition of Christian reflection and practice on democracy in the Netherlands.... The neo-Calvinist movement developed distinctive ideas of the public sphere, the private sphere, religion and the "secular" from out of its Christian beliefs. In particular, Abraham Kuyper drew up a principled neo-Calvinist approach to, and rationale for, a tolerant democratic order in the Netherlands. His thinking helped many in this community to understand, support and participate in "constitutional democracy" and "principled public pluralism," from the nineteenth century to the present. ${ }^{83}$

Pengamalan kuat akan "sovereignty of God over all of life" yang sekaligus memperjuangkan demokrasi dan pluralisme telah dikumandangkan Kuyper dan tradisi Neo-Calvinisme sejak awal. Seperti telah dipaparkan sebelumnya, bahwa penolakan utama Kuyper terhadap Revolusi Prancis adalah pada konsep "no gods, no masters", bukan menolak konsep kebebasannya. Kuyper sangat menentang semangat Revolusi Prancis yang atheistik dengan semangat Calvinisme yang dikonstruksi sebagai "life system." Seperti yang dikemukakan Chaplin:

.... both divine and human appointment are required for the establishment of legitimate political authority. Political authority as such is seen as originating in God, operating either through creation or providence, rather than in autonomous popular will... that there is a necessary role for popular participation, expressed in various ways, in the public legitimizing of those who exercise the divinely authorized office of government. ${ }^{84}$

82 John L. Esposito and John O. Voll, “Islam and Democracy," Humanities 22, no. 6 (2001): 22.

83 John L. Hiemstra, "A Calvinist Case for Tolerant Public Pluralism: The Religious Sources of Abraham Kuyper's Public Philosophy," Religious Studies and Theology 34, no. 1 (2015): 55.

84 Jonathan Chaplin, "Christian Justification for Democracy," Ethics in Brief 11, no. 3 (2006): 2. 
Dengan demikian, Pancasila yang telah dipakai oleh Soekarno untuk menerobos jalan buntu perdebatan antara faksi nasionalis dan faksi Islam, akan semakin diperkuat melalui perspektif pluralisme prinsipiil.

\section{Interpretasi Pluralisme Prinsipiil pada Pancasila}

Meskipun Pancasila dan pluralisme prinsipiil terdapat kesesuaian hubungan agama dan negara, Pancasila masih kurang dalam mengelaborasinya. Perspektif pluralisme prinsipiil dibutuhkan untuk memberi interpretasi kepada Pancasila demi tercapainya tujuan Pancasila itu sendiri.

Sila pertama dalam Pancasila, yaitu Ketuhanan yang maha esa, jika dilihat dari perspektif pluralisme prinsipiil, harus mempresuposisikan akan kedaulatan Allah, ${ }^{85}$ karena kedaulatan Allah adalah sumber segala otoritas manusia. ${ }^{86}$ Mengutip Darmaputera, posisi Ketuhanan yang maha esa yang ditempatkan pertama, harus dilihat sebagai "the guiding principle" bagi keempat sila lainnya dan dalam pengertian tertentu sila kedua, ketiga, keempat, dan kelima tunduk kepada sila pertama. ${ }^{87}$

Tanpa kedaulatan Allah yang mendasari keempat sila lainnya, Pancasila bisa jatuh kepada liberalisme di mana individualitas yang diberikan Allah berubah menjadi individualisme yang menundukkan struktur-struktur sosial di bawah otoritasnya. ${ }^{88}$ Seperti yang dikemukakan oleh Herman Dooyeweerd bahwa "a watertight division between state and church, and introduce the "religionless state," where faith is completely excluded." 89 Sebaliknya, dengan mengakui kedaulatan Allah, seorang individu selain sadar memiliki kebebasan, ia juga sadar akan adanya dimensi transendental ${ }^{90}$ dan konsep benar-salah di hadapan Allah. ${ }^{91}$

Dengan menempatkan sila ketuhanan di tempat yang teratas, bukan berarti agama (secara institusi) juga ditempatkan di atas. Penempatan tersebut akan menyalahi structural pluralism karena agama akan merampas otoritas yang dimiliki oleh negara (theocratic). Kuyper berargumen bahwa teokrasi hanya berlaku pada zaman Israel. Lebih lanjut, menurut Chaplin, pada zaman gereja mula-mula Kristen jauh dari teokrasi:

85 Intan, "Religious Freedom and The Pancasila-Based State of Indonesia: A Neo-Calvinist Idea of Principled Pluralism."

86 Kuyper, Lectures on Calvinism, 90.

87 Intan, "Religious Freedom and The Pancasila-Based State of Indonesia: A Neo-Calvinist Idea of Principled Pluralism."

88 David T. Koyzis, Political Visions \& Illusions: A Survey \& Christian Critique of Contemporary Ideologies (Downers Grove: IVP Academic, 2003), 133.

89 Herman Dooyeweerd, The Christian Idea of the State (Nutley: Craig, 1968), 49-50.1936

90 Intan, "Religious Freedom and The Pancasila-Based State of Indonesia: A Neo-Calvinist Idea of Principled Pluralism."

91 Koyzis, Political Visions \& Illusions, 189. 
....the early church was born entirely outside the parameters of public power, did not seek it, and regarded itself as a radical counter-cultural community rejecting many of the vaunted public values of imperial Roman society: glory, military prowess, social hierarchy, contempt for the weak, paternalistic benevolence - which is why it experienced periodic persecution from Roman authorities. ${ }^{92}$

Di sini jelaslah bahwa pluralisme prinsipiil bertentangan dengan segala usaha yang pernah dilakukan oleh gereja di dalam sejarah untuk menguasai negara.

Structural pluralism juga harus dipakai untuk menafsirkan apa yang Soekarno kumandangkan pada pidato Lahirnya Pancasila ketika mendorong orang Islam untuk banyak masuk ke dalam pemerintahan agar hukum negara berdasarkan hukum Islam, dan juga ketika ia mendorong orang Kristen banyak masuk ke dalam pemerintahan agar hukum negara berdasarkan injil. ${ }^{93}$ Jika ditafsirkan berdasarkan structural pluralism, jelaslah Soekarno tidak menghendaki adanya Perda Syariah maupun Perda Injil karena dalam hal ini agama sedang merampas otoritas negara. Di sini structural pluralism membantu membedakan natur inti dari agama dan negara dengan jelas. Natur inti dari agama adalah iman, yaitu arah hati kepada Tuhan maupun bukan Tuhan, sedangkan natur inti dari negara adalah yuridis, yaitu hukum yang seimbang dalam mengharmonisasi keberagaman interes dan menangkal segala aktualisasi yang berlebihan akan perhatian khusus yang merugikan orang lain. ${ }^{94}$ Sebagai contoh, jalan raya (negara) yang digunakan oleh berbagai struktur dalam masyarakat, harus diatur supaya tidak ada yang dirugikan, baik dalam aspek moral, sosial, ekonomi, pendidikan, dan sebagainya. Ketika ada suatu kelompok agama yang mau menggunakannya untuk melakukan suatu ibadah dan menimbulkan kemacetan panjang, maka akan banyak kerugian yang terjadi dalam berbagai aspek. Di sini negara wajib mengatur ketertiban umum termasuk harus melarang (tidak memberikan izin) kelompok agama untuk menggunakan jalan raya sebagai tempat ibadah. Meskipun Pancasila dan UUD 45 menjamin kebebasan beragama, bukan berarti kebebasan tanpa batas. Chaplin memberi contoh extrem mengenai suku Aztec yang mengorbankan nyawa manusia dalam ritualnya, jelas harus dilarang oleh negara. ${ }^{95}$ Maka jelaslah bahwa structural pluralism yang melakukan pembedaan peran antar institusi-institusi dapat mencegah perampasan otoritas dalam negara Pancasila.

92 Jonathan Chaplin, "Faith, Power and the State: A Starting-Point for a Christian-Muslim Exchange," Crucible (Oktober 2017): 6.

93 Soekarno, "Pidato Lahirnya Pancasila 1 Juni 1945."

94 L. Kalsbeek, Contours of a Christian Philosophy (Toronto: Wedge Pub Foundation, 1975), 102.

95 Chaplin, "Faith, Power and the State: A Starting-Point for a Christian-Muslim Exchange," 9. 
Ketika Pancasila menyesuaikan diri dengan structural pluralism, maka pada saat yang sama sedang mendukung confessional pluralism. Di sinilah pemisahan antara agama dan negara dihindarkan, sehingga yang terjadi adalah kooperasi antara agama dan negara. ${ }^{96}$ Maka kebebasan agama jika ingin berkiprah di ranah publik, termasuk berpolitik dan bernegara, harus dilakukan pada taraf civil society. Agama di ranah publik pada level civil society mempunyai misi memberdayakan kekuatan potensial agama-agama dalam menjawab tantangan konkret kemanusiaan di dalam masyarakat. Fokusnya bukan pada isu dominasi antar kelompok agama, tetapi bagaimana agama-agama tampil sebagai kekuatan demokratis dalam mentransformasi kehidupan sosial-politik masyarakat.

Maka apa yang disampaikan Soekarno ketika ia mendorong penganut agama Islam maupun agama Kristen untuk masuk pemerintahan dan memberi pengaruh berdasarkan nilai agama yang dipercayai, harus dilihat dengan kacamata confessional pluralism. Dalam hal ini Indonesia juga memiliki dukungan secara historis, yaitu agama Islam dan Kristen telah memberikan kontribusinya di dalam perjuangan kemerdekaan Indonesia. ${ }^{97}$ Oleh sebab itu dapat disimpulkan bahwa Pancasila dan confessional pluralism memiliki hubungan yang selaras.

\section{Kesimpulan}

Pancasila sebagai dasar negara Indonesia yang sangat majemuk sangatlah cocok karena memberikan kebebasan bagi semua agama untuk menjalankan agamanya masing-masing bukan hanya di ranah privat tetapi juga ranah publik. Namun Pancasila selama ini tetap kurang memadai di dalam elaborasinya, sehingga membutuhkan pengejawantahan yang lebih fondasional dan konsisten. Pluralisme prinsipiil dari Neo-Calvinisme yang terindikasi memiliki pengaruh pada lahirnya Pancasila, akan banyak membantu di dalam mengisi apa yang menjadi kekurangan dari Pancasila itu sendiri.

96 Chaplin, 9.

97 Binsar A. Hutabarat, "Ambiguitas Diferensiasi Agama dan Negara di Indonesia," Societas Dei: Jurnal Agama Dan Masyarakat 05, No. 1 (2018): 16-17. 